\title{
Metallic Content of One Hundred Medicinal Plants
}

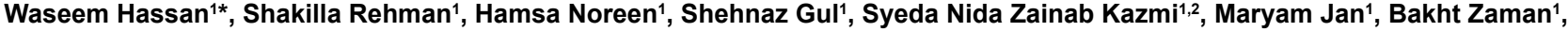 Ata Ur Rehman ${ }^{1}$, Ziarat Shah' ${ }^{1}$, Ali Riaz ${ }^{2}$ and Imdad Ullah Mohammadzai ${ }^{1}$}

${ }^{1}$ Institute of Chemical Sciences, University of Peshawar, Peshawar -25120, Khyber Pakhtunkhwa, Pakistan

${ }^{2}$ Department of Chemistry, Sarhad University of Science and Information Technology, Peshawar -25120, Khyber Pakhtunkhwa, Pakistan

\begin{abstract}
Heavy metals are necessary for the normal functioning of cells and the survival of organisms. These are required for physiological and biochemical functioning of the body, but at higher concentration they causes the oxidative damage. In fact non-essential metals like (lead $(\mathrm{Pb})$, mercury $(\mathrm{Hg})$ and cadmium $(\mathrm{Cd})$ ) are more noxious even at very low concentration. It's important to note that heavy metals are present in soil, air and water can easily enter into the organisms. Literature highlighted the role of metals like chromium $(\mathrm{Cr})$, iron $(\mathrm{Fe})$, nickel $(\mathrm{Ni})$, copper $(\mathrm{Cu})$, cadmium $(\mathrm{Cd})$, lead $(\mathrm{Pb})$ and arsenic $(\mathrm{As})$ in oxidative damage. Fenton chemistry/Haber-Weiss reaction are most extensively studied mechanisms by which heavy metals produces reactive oxygen and nitrogen species (ROS and RNS) and ultimately causes oxidative stress. Both redox-active and inactive metals can diminish cellular antioxidant system specifically thiol- containing enzymes and antioxidants and may lead to cellular death. This review will contribute in providing valuable information on metallic contents of selected plants. For the purpose, data has been collected from the literature regarding ten mineral contents (sodium $(\mathrm{Na})$, potassium $(\mathrm{K})$, calcium $(\mathrm{Ca})$, magnesium $(\mathrm{Mg})$, zinc $(\mathrm{Zn})$, iron $(\mathrm{Fe})$, copper $(\mathrm{Cu})$, chromium $(\mathrm{Cr})$, nickel $(\mathrm{Ni})$ and manganese $(\mathrm{Mn}))$ of 100 medicinal plants grown in Pakistan. The metallic contents shows that majority of the plants contain optimum values as compared with daily mineral intake standards. However, several factors may account for variations in mineral concentration, which include soil composition, different geographic areas and environmental changes.
\end{abstract}

Keywords: Plants; Ethnobotanical uses; Metallic content

\section{Ethnobotanical Uses of 100 Medicinal Plants}

Medicinal plants are considered as key sources of drugs for the treatment of various ailments worldwide. The flora of Pakistan due to its highly favorable diverse climatic and soil conditions, many topographical regions and ecological zones offer a great variety of medicinal plants [1]. According to a general survey, approximately 6000 flowering plants exist in Pakistan, out of which 400-600 are utilized for medicinal purposes [2,3]. Literature reported that about $80 \%$ of the rural population of Pakistan relies primarily on traditional medicines while $90 \%$ of the country's medicinal herbs are imported [4,5].

Furthermore, all the selected plants are utilized by the native people for cure of various diseases such as diarrhea, dysentery, stomach disorders, pain, wounds, skin diseases, scrofula, ulcers, urinary tract infections, bronchitis, asthma, whooping cough, loose motion, emmenagogues, toothaches, rheumatism, sensory and nervous system dysfunctions, sexual disorders, kidney troubles, piles, jaundice, hepatitis, typhoid, malarial fevers, heart diseases and immune deficiency diseases [1-5].

\section{Metallic Content of 100 Medicinal Plants}

Mineral elements are assumed of immense value as each of these elements show a distinctive individual role in the structural and functional integrity of the organization of living systems. Although minerals comprise only $4-6 \%$ of the human body and do not take part efficiently in fulfilling the energy requirements, yet their importance can be established from their involvement in a large number of physicochemical processes of utmost importance which takes place continuously in living cells and organisms [6,7]. Minerals may be generally classified as macro (sodium $(\mathrm{Na})$, calcium $(\mathrm{Ca})$, phosphorus (p)and chlorine $(\mathrm{Cl})$ ) or micro (manganese $(\mathrm{Mn})$, zinc $(\mathrm{Zn})$, iron $(\mathrm{Fe})$, potassium $(\mathrm{K})$, magnesium $(\mathrm{Mg})$, copper $(\mathrm{Cu})$, cobalt $(\mathrm{Co})$ and chromium $(\mathrm{Cr})$ ) elements which mostly depend on their requirements to the body and it has been found that approximately more than $100 \mathrm{mg} /$ $\mathrm{dl}$ of the macronutrients and less than $100 \mathrm{mg} / \mathrm{dl}$ of the micronutrients are necessary on daily basis $[6,8]$. Deficiencies of the mineral elements are the foremost public health problem in many under developed countries with women and infants at high risk [9]. Studies have shown that severe cases of anaemia most likely due to mineral deficiencies are a direct cause of child and maternal mortality [10].

The medicinal plants serve as a good source of these vital mineral elements which can be consumed both for dietary and medicinal purposes. However the lack of knowledge regarding the mineral quantities in these plants often produce hazardous effects on consumers health as various plants contain toxic metals in sufficient higher amounts. Thus metallic screening of medicinal plants is of immense importance [11]. This review will contribute in providing valuable information on metallic contents of selected plants and both the beneficial and harmful effects of the minerals on human health. For the purpose, data has been collected from literature regarding ten mineral contents $(\mathrm{Na}, \mathrm{K}, \mathrm{Ca}, \mathrm{Mg}, \mathrm{Zn}, \mathrm{Fe}, \mathrm{Cu}, \mathrm{Cr}, \mathrm{Ni}$ and $\mathrm{Mn}$ ) of 100 medicinal plants grown in Pakistan.

The data concerning sodium $(\mathrm{Na})$ content of the selected medicinal plants have been obtained from the literature and presented in (Table 1). The highest amounts of $\mathrm{Na}$ are present in S.cordifolia (3.649\%) Z.mauritiana $(34.16 \mathrm{mg} / \mathrm{g}$ ) and E.ribes (12500 ppm). Plants like D.sisso (0.07 ppm), P.granatum (1.279 $\pm 0.003 \mathrm{mg} / \mathrm{L})$, R.communis (1.64 ppm) and T.terrestris $(1.70 \mathrm{mg} / \mathrm{kg})$ contain lower amounts of $\mathrm{Na}$, while the

*Corresponding author: Waseem Hassan, Institute of chemical sciences, University of Peshawar, Peshawar -25120, Khyber Pakhtunkhwa, Pakistan, Tel: 0092-91-9216652; E-mail: waseem_anw@yahoo.com

Received November 05, 2015; Accepted November 28, 2015; Published December 03, 2015

Citation: Hassan W, Rehman S, Noreen H, Gul S, Kazmi SNZ, et al. (2015) Metallic Content of One Hundred (100) Medicinal Plants. J Nutr Disorders Ther 5 177. doi:10.4172/2161- 0509.1000177

Copyright: @ 2015 Hassan W, et al. This is an open-access article distributed under the terms of the Creative Commons Attribution License, which permits unrestricted use, distribution, and reproduction in any medium, provided the original author and source are credited. 
Citation: Hassan W, Rehman S, Noreen H, Gul S, Kazmi SNZ, et al. (2015) Metallic Content of One Hundred (100) Medicinal Plants. J Nutr Disorders Ther 5: 177. doi:10.4172/2161- 0509.1000177

Page 2 of 9

\begin{tabular}{|c|c|c|c|c|c|c|c|c|c|c|c|}
\hline $\begin{array}{l}\text { Sr. } \\
\text { No. }\end{array}$ & Plant name & $\mathrm{Na}$ & $\mathbf{K}$ & $\mathrm{Ca}$ & Mg & Zn & $\mathrm{Fe}$ & $\mathrm{Cr}$ & $\mathrm{Cu}$ & $\mathrm{Ni}$ & Mn \\
\hline 1. & Terminaliaarjuna(ppm) [51] & & 5900 & 3500 & 12100 & 76 & 750 & & & 10 & 86 \\
\hline 2. & Bauhinia variegate $(\mathrm{mg} / \mathrm{kg})$ [51] & & & $\begin{array}{c}560 \pm \\
40.9\end{array}$ & $\begin{array}{l}545 \pm \\
50.0\end{array}$ & $37 \pm 2.2$ & $53 \pm 1.6$ & & & & $18 \pm 0.6$ \\
\hline 3. & Cuminumcyminum(ppm) [52] & 0.27 & 1.81 & 0.96 & 0.48 & 33 & 229 & & 21 & & 35 \\
\hline 4. & Violaodorata(ppm) [53] & 528 & 100 & 78 & 11.2 & 2.17 & 19.4 & & & & \\
\hline 5. & $\begin{array}{l}\text { Capsellabursa pestoris(ppm) } \\
\text { [54] }\end{array}$ & & & & & 11.4 & 212 & 1 & 4.3 & 3.1 & 29 \\
\hline 6. & Allium sativum (mg/100g) [55] & $4.10 \pm 0.14$ & $\begin{array}{c}54.00 \pm \\
1.40\end{array}$ & $\begin{array}{c}26.30 \pm \\
0.14\end{array}$ & $\begin{array}{c}4.10 \pm \\
0.14\end{array}$ & $\begin{array}{c}0.34 \pm \\
0.17\end{array}$ & $5.29 \pm 0.08$ & & $.001 \pm 0.0$ & & $0.001 \pm 0.0$ \\
\hline 7. & Minthaspicata(ppm)[56] & $147.7 \pm 4.68$ & $\begin{array}{c}15.56 \pm \\
0.51\end{array}$ & $\begin{array}{c}255.95 \pm \\
9.01\end{array}$ & $\begin{array}{c}3.90 \pm \\
0.14\end{array}$ & $\begin{array}{l}0.79 \pm \\
0.025\end{array}$ & $2.03 \pm 0.052$ & - & $0.88 \pm 045$ & - & - \\
\hline 8. & Trigonellafoenum(ppm) [54] & 270 & 50 & 88 & 11 & 2.24 & 14.2 & & & & \\
\hline 9. & Euphorbia tirucalli & - & - & - & - & - & - & - & - & - & - \\
\hline 10. & Cyperusrotundus & - & - & - & - & - & - & - & - & - & - \\
\hline 11. & Saussureaelappa & - & - & - & - & - & - & - & - & - & - \\
\hline 12. & Fumariaindica & - & - & - & - & - & - & - & - & - & - \\
\hline 13. & Solanumnigrum( $\mathrm{mg} / \mathrm{kg}$ ) [57] & $810.77 \pm 57.69$ & & & $\begin{array}{c}185.92 \pm \\
6.12\end{array}$ & $8.53 \pm 0.29$ & $311.88 \pm 5.02$ & & $\begin{array}{l}17.471 \pm \\
.84\end{array}$ & & $98.43 \pm 3.67$ \\
\hline 14. & Zizyphusjujoba (mg/100g)[58] & $6.21 \pm 0.24$ & $375 \pm 6.3$ & $45.6 \pm 2.1$ & & $\begin{array}{l}0.47 \pm \\
0.06\end{array}$ & $6.42 \pm 0.12$ & & $0.42 \pm 0.02$ & & $51.2 \pm 2.8$ \\
\hline \multirow{2}{*}{15.} & \multirow{2}{*}{ Eugenia aromatic $(\mathrm{ug} / \mathrm{g})[59]$} & 2409 & 1618 & & & 4.94 & 60.03 & 0.96 & 3.24 & 0.7 & 57.3 \\
\hline & & \pm 81.60 & \pm 135.6 & & & \pm 1.228 & \pm 0.785 & \pm 0.109 & \pm 0.261 & \pm 0.082 & \pm 6.826 \\
\hline 16. & Glycyrrhizaglabra(mg/100g) [60] & $63.20 \pm 0.56$ & $\begin{array}{c}180.48 \pm \\
0.12\end{array}$ & & & $\begin{array}{c}00.96 \pm \\
0.01\end{array}$ & $08.08 \pm 0.02$ & & & & \\
\hline 17. & Piper longum & - & - & - & - & - & - & - & - & - & - \\
\hline 18. & Crocus sativus (mg/100g)[61] & $25.75 \pm 0.01$ & $\begin{array}{c}542.13 \pm \\
0.01\end{array}$ & $\begin{array}{c}486.25 \pm \\
0.12\end{array}$ & $\begin{array}{c}2.93 \pm \\
0.02\end{array}$ & $\begin{array}{c}1.80 \pm \\
0.13\end{array}$ & $17.99 \pm 0.09$ & & $\begin{array}{l}0.87 \pm \\
0.008\end{array}$ & & \\
\hline 19. & Pipernigrum & - & - & - & - & - & - & - & - & - & - \\
\hline 20. & Tagetesminuta (ppm) [53] & 208 & 80 & 109 & 11.5 & 2.33 & 14.3 & ND & ND & ND & ND \\
\hline 21. & Thymuslinearis & - & - & - & - & - & - & - & - & - & - \\
\hline 22. & Carumcarvi ( mg/kg) [53] & 0.1 & 44.5 & 11.8 & 3.1 & 22.3 & 74.7 & 0.3 & 5.2 & 59.8 & ND \\
\hline 23. & Menthapiperata ( $\mathrm{mg} / \mathrm{kg}$ ) [62] & & & 12150 & 3602 & 12.64 & 531.5 & 5.41 & 11.5 & & 70.8 \\
\hline 24. & Acaciamodesta (ppm) [63] & 1.8 & 19000 & & & 10.2 & & & 3.4 & & \\
\hline 25. & Nigella sativa( mg/kg) [64] & $0.35 \pm 0.02$ & $\begin{array}{l}0.83 \pm \\
0.01 \%\end{array}$ & $\begin{array}{l}9.13 \pm \\
0.16\end{array}$ & $\begin{array}{c}10.20 \pm \\
0.09\end{array}$ & $\begin{array}{c}0.05 \pm \\
0.00\end{array}$ & $0.26 \pm 0.02$ & & $0.03 \pm 0.00$ & & $103.9 \pm 3.69$ \\
\hline 26. & Acacia nilotica (ppm) [65] & 87.25 & 549 & 2.08 & 2.075 & & & & & & \\
\hline \multirow{2}{*}{27.} & \multirow{2}{*}{ Adhatodavasica [66] } & & 2000 & 20900 & 20500 & & \multirow{2}{*}{1250} & & & & \multirow{2}{*}{67} \\
\hline & & & ppm & ppm & ppm & & & & & & \\
\hline \multirow{2}{*}{28.} & Psidiumguajava & \multirow{2}{*}{750.9} & \multirow{2}{*}{895} & \multirow{2}{*}{172} & & \multirow{2}{*}{1.84} & \multirow{2}{*}{11.71} & & \multirow{2}{*}{1.38} & & \multirow{2}{*}{1.38} \\
\hline & $(\mathrm{mg} / \mathrm{1oog})$ [67] & & & & 158.7 & & & & & & \\
\hline 29. & Cassia fistula (\%) [68] & 118.4 & 838 & 925 & 947.4 & 70.67 & 179.5 & & & & 37.2 \\
\hline \multirow[t]{2}{*}{30.} & \multirow[t]{2}{*}{ Cannabis sativa [69] } & \multirow[t]{2}{*}{-} & \multirow[t]{2}{*}{-} & \multirow[t]{2}{*}{-} & \multirow[t]{2}{*}{-} & $\begin{array}{c}2.25 \pm \\
0.01\end{array}$ & $135.20 \pm 0.12$ & - & $26.6 \pm 0.01$ & - & $40.30 \pm 0.05$ \\
\hline & & & & & & $\mathrm{mg} / \mathrm{l}$ & $\mathrm{mg} / \mathrm{l}$ & & $\mathrm{mg} / \mathrm{l}$ & & \\
\hline 31. & Allium cepa $(\mathrm{mg} / 100 \mathrm{~g})[70]$ & 5.4 & 140 & 22 & 20 & 2 & 0.2 & - & - & - & - \\
\hline 32. & $\begin{array}{l}\text { Phoenix dactylifera(mg/100 g) } \\
\text { [71] }\end{array}$ & $3.49 \pm 0.12$ & $624 \pm 5$ & $81.9 \pm 1.9$ & $\begin{array}{c}60.9 \pm \\
1.2\end{array}$ & $\begin{array}{c}0.45 \pm \\
0.02\end{array}$ & $0.60 \pm 0.11$ & $\begin{array}{c}0.01 \pm \\
0.02\end{array}$ & $0.77 \pm 0.03$ & & $0.30 \pm 0.04$ \\
\hline 33. & chenopodium album (ppm) [72] & 375 & 10455 & 4242 & 45460 & 0.2 & 102.8 & 1.8 & 4.3 & 0.3 & \\
\hline 34. & Abutilon indicum $(\mathrm{mg} / 100 \mathrm{~g})[73]$ & & $\begin{array}{c}261.01 \pm \\
0.01\end{array}$ & $\begin{array}{c}237.32 \pm \\
0.03\end{array}$ & $\begin{array}{c}176.50 \pm \\
0.052\end{array}$ & $\begin{array}{c}1.94 \pm \\
0.03\end{array}$ & $3.13 \pm 0.10$ & & & & \\
\hline 35. & $\begin{array}{l}\text { Zanthoxylumarmatum }(\mathrm{m} / 100 \mathrm{~g}) \\
\text { [74] }\end{array}$ & $5.84 \pm 2.09$ & $\begin{array}{l}87.84 \pm \\
8.34\end{array}$ & $\begin{array}{c}96.78 \pm \\
6.86\end{array}$ & $\begin{array}{c}9.80 \pm \\
2.61\end{array}$ & $\begin{array}{c}0.032 \pm \\
0.012\end{array}$ & $0.425 \pm 0.02$ & ND & $6.34 \pm 2.69$ & & $\begin{array}{c}0.043 \pm \\
0.017\end{array}$ \\
\hline 36. & Citrus limon $(\mathrm{mg} / 100 \mathrm{~g})[75]$ & $755.50 \pm 0.058$ & $\begin{array}{c}8600.00 \pm \\
0.028\end{array}$ & $\begin{array}{c}8452.50 \pm \\
0.050\end{array}$ & $\begin{array}{l}1429.50 \\
\pm 0.008\end{array}$ & $\begin{array}{c}13.94 \pm \\
0.007\end{array}$ & $\begin{array}{c}147.65 \pm \\
0.068\end{array}$ & & $\begin{array}{l}4.94 \pm \\
0.012\end{array}$ & & \\
\hline 37. & Sidacordifolia (\%) [76] & 3.649 & 10.2 & 13.1 & & 5.163 & 1.135 & 1.31 & 8.9 & & 1.86 \\
\hline 38. & Corriandrumsativum (ppm) [77] & & & & & 59.4 & 150.4 & $<0.003$ & 41.4 & $<0.006$ & \\
\hline 39. & Ricinuscommunis (ppm) [78] & $1.64 p$ & 0.79 & 3.21 & 0.19 & 0.49 & 4.1 & 3.41 & 5.2 & & 0.92 \\
\hline 40. & Lepidiumsativum $(\mathrm{mg} / 100 \mathrm{~g})$ [79] & 12.4 & 85.3 & 8.2 & 31.8 & 1 & 1.1 & & 0.1 & & 0.3 \\
\hline 41. & Sesamumindicum $(\mathrm{mg} / \mathrm{kg})[80]$ & $122.50 \pm 4.21$ & $\begin{array}{c}851.35 \pm \\
3.44\end{array}$ & $\begin{array}{c}415.38 \pm \\
3.14\end{array}$ & $\begin{array}{c}579.53 \pm \\
0.42\end{array}$ & & & & & & \\
\hline
\end{tabular}


Citation: Hassan W, Rehman S, Noreen H, Gul S, Kazmi SNZ, et al. (2015) Metallic Content of One Hundred (100) Medicinal Plants. J Nutr Disorders Ther 5: 177. doi:10.4172/2161- 0509.1000177

Page 3 of 9

\begin{tabular}{|c|c|c|c|c|c|c|c|c|c|c|c|}
\hline 42. & Curcuma longa (mg/kg) [81] & 210 & 7940 & 0.12 & 0.28 & 57.06 & & & 5.71 & & 429 \\
\hline 43. & Grewiaoptiza (\%) [82] & 0.15 & 0.64 & 3.35 & & & & & & & \multirow{3}{*}{$6 \pm 0.05$} \\
\hline \multirow{2}{*}{44.} & \multirow{2}{*}{ Valerianawallichii(ppm) [83] } & & & & & $11.64 \pm$ & 140.8 & 266 & $11.28 \pm$ & & \\
\hline & & & & & & 0.11 & \pm 0.17 & \pm 0.12 & 0.06 & & \\
\hline 45. & Tribulusterrestris (mg/kg) [84] & 1.7 & 55 & 28 & 32 & & & & & & \\
\hline 46. & $\begin{array}{l}\text { Origanumvulgare }(\mathrm{mg} / \mathbf{1 0 0 g}) \\
\text { [85] }\end{array}$ & 47.2 & 1970 & 164 & 80.67 & 1.5 & 17.26 & 0.26 & 0.58 & 0 & 0.77 \\
\hline 47. & Daturastromium (mg/g) [75] & 2.5 & 2.5 & 295 & 307.5 & 0.51 & 5.63 & 2.85 & 8.07 & & 8.49 \\
\hline 48. & Swertiachirata (ppm) [86] & & & & & 45.4 & & & 9.8 & & \\
\hline 49. & Punicagranatum (mg/L) [87] & $1.279 \pm 0.003$ & $\begin{array}{c}55.19 \pm \\
0.021\end{array}$ & $\begin{array}{c}1.650 \pm \\
0.00\end{array}$ & $\begin{array}{c}3.721 \pm \\
0.001\end{array}$ & $\begin{array}{c}0.430 \pm \\
0.001\end{array}$ & $0.466 \pm 0.003$ & & $\begin{array}{l}0.231 \pm \\
0.003\end{array}$ & & $\begin{array}{l}0.033 \pm \\
0.002\end{array}$ \\
\hline 50. & Cedrusdeodara (mg/100g) [88] & & 0.06 & 2.6 & 0.017 & & & & & & \\
\hline 51. & $\begin{array}{l}\text { Hippophaërhamnoides (ppm) } \\
\text { [54] }\end{array}$ & - & - & - & - & 8.1 & 87 & 0.4 & 4.5 & 4 & 122 \\
\hline \multirow{2}{*}{52.} & Menthalongifolia & $373.1 \pm 0.40$ & $8372 \pm 16$ & $2810 \pm 10$ & $\begin{array}{c}3350 \pm \\
13\end{array}$ & 0.84 & \multirow{2}{*}{0.12 [69] } & \multirow{2}{*}{0.51} & \multirow{2}{*}{$0.58[69]$} & & 0.25 \\
\hline & $(\mu \mathrm{g} / \mathrm{g}) . / \mathrm{mg} / \mathrm{l}) \pm \mathrm{SD}$ & [89] & [89] & [89] & [89] & [69] & & & & & [69] \\
\hline \multirow[t]{2}{*}{53.} & \multirow[t]{2}{*}{ Juglansregia (mg/100 g) [90] } & $0.25 \pm 0.02$ & \multirow[t]{2}{*}{3.02} & \multirow[t]{2}{*}{0.79} & \multirow[t]{2}{*}{0.51} & \multirow{2}{*}{$\begin{array}{c}3.19 \pm \\
0.85[91]\end{array}$} & $5.88 \pm 1.10$ & $\begin{array}{c}0.85 \pm \\
0.44\end{array}$ & $3.12 \pm 1.48$ & \multirow[t]{2}{*}{ * } & \multirow{2}{*}{$\begin{array}{c}10.45 \pm 5.12 \\
{[91]}\end{array}$} \\
\hline & & [91] & & & & & [91] & [91] & [91] & & \\
\hline 54. & Plantago ovata (ug/g) [72] & $1200 \pm 60$ & $1000 \pm 60$ & $1600 \pm 80$ & $\begin{array}{c}63.5 \pm \\
10.5\end{array}$ & $\begin{array}{c}99.4 \pm \\
10.8\end{array}$ & $21.7 \pm 4.8$ & $\begin{array}{c}11.754 \pm \\
0.01\end{array}$ & $59 \pm 7.3$ & $\begin{array}{c}0.0213 \pm \\
0.0001\end{array}$ & $6.0 \pm 1.2$ \\
\hline \multirow{2}{*}{55.} & \multirow{2}{*}{ Berberislyceum [92] } & $14.5 \pm 0.11$ & \multirow{2}{*}{$\begin{array}{c}161.42 \\
\pm 0.41 \\
\mathrm{mg} / 100 \mathrm{~g}\end{array}$} & 18.272 & $0.541 \%$ & $\begin{array}{c}27.50 \mathrm{mg} / \\
\mathrm{kg}\end{array}$ & $2649.99 \mathrm{mg} /$ & & $\begin{array}{c}33.50 \mathrm{mg} / \\
\mathrm{kg}\end{array}$ & & $\begin{array}{c}58.67 \mathrm{mg} / \\
\mathrm{kg}\end{array}$ \\
\hline & & $\mathrm{mg} / 100 \mathrm{~g}$ & & & [93] & [93] & $\mathrm{kg}[93]$ & & [93] & & [93] \\
\hline & & & & & & 44.1 & 349.5 & 4 & 33 & 7 & \\
\hline 56. & Withaniasomnifera (\%) [94] & 0.54 & 2.2 & 0.16 & 0.184 & ppm & ppm & ppm [95] & $\mathrm{ppm}$ & ppm [95] & 59.0 ppm \\
\hline 57. & Dalberqiasisso [13] & 0.07 & 2.4 & 64.5 & 7.4 & * & 1.5 & * & * & * & 0.03 \\
\hline 56. & Dalberglasisso [13] & \pm 0.02 & \pm 0.70 & \pm 1.60 & \pm 0.50 & 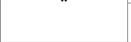 & \pm 0.10 & & 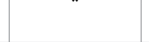 & $n$ & \pm 0.01 \\
\hline 58. & Pyruspyrifolia (mg/100 g) [96] & 4 & 96 & 9 & 7 & 0.09 & 0.29 & - & 0.05 & - & 0.03 \\
\hline 59. & $\begin{array}{l}\text { Vernoniaamygdalina }(\mathrm{mg} / 100 \mathrm{~g}) \\
\text { [97] }\end{array}$ & - & - & - & $\begin{array}{c}0.43 \pm \\
0.00\end{array}$ & $\begin{array}{c}0.04 \pm \\
0.01\end{array}$ & $0.14 \pm 0.01$ & $\begin{array}{c}0.04 \pm \\
0.01\end{array}$ & $0.10 \pm 0.00$ & - & $0.07 \pm 0.03$ \\
\hline 60. & $\begin{array}{l}\text { Trachyspermumammi (ug/g) } \\
\text { [98] }\end{array}$ & - & - & - & - & $\begin{array}{c}80.6 \pm \\
24.1\end{array}$ & $2792 \pm 304$ & - & $145 \pm 27$ & - & $771 \pm 11$ \\
\hline 61. & Caricapapaya (mg/100 g) [99] & 4 & 223 & 24.9 & 23.54 & 0.056 & 2.56 & - & 0 & - & 0.01 \\
\hline 62. & $\begin{array}{l}\text { Citrulluscolocynthis (mg/100g) } \\
\text { [100] }\end{array}$ & $1.75 b \pm 0.01$ & $\begin{array}{l}2.85 \mathrm{c} \pm \\
0.05\end{array}$ & $\begin{array}{l}1.90 \mathrm{~b} \pm \\
0.01\end{array}$ & $\begin{array}{c}1.10 b \pm \\
0.02\end{array}$ & $\begin{array}{l}0.31 \mathrm{a} \pm \\
0.02\end{array}$ & $0.10 b \pm 0.01$ & * & $\begin{array}{l}0.10 \mathrm{a} \pm \\
0.01\end{array}$ & * & \\
\hline 63. & $\begin{array}{l}\text { AzadirachtaindicaA. } \\
\text { Juss }(\mathrm{mg} / 100 \mathrm{~g})[101]\end{array}$ & - & & - & \begin{tabular}{|l|}
$0.69 \pm$ \\
$0.01 \%$ \\
\end{tabular} & $\begin{array}{c}0.06 \pm \\
0.01\end{array}$ & $0.14 \pm 0.01$ & $\begin{array}{l}0.58 \pm \\
0.00^{*}\end{array}$ & $\begin{array}{l}0.06 \pm \\
0.01^{*}\end{array}$ & 0 & $0.06 \pm 0.03$ \\
\hline 64. & $\begin{array}{l}\text { Raphanussativus(mg/100 g) } \\
\text { [102] }\end{array}$ & $10.7 a^{* *}$ & $209 a^{* *}$ & $21.0 \mathrm{c}^{\star *}$ & $10.2 b^{* *}$ & $0.09 b^{* *}$ & $0.73 b^{* *}$ & $0.01 c^{* *}$ & $0.07 a^{*}$ & $0.07 a^{* *}$ & $0.09 b^{* *}$ \\
\hline 65. & $\begin{array}{l}\text { Tamarindusindica(mg/100 g) } \\
\text { [103] }\end{array}$ & $40.20 \mathrm{a} \pm 0.10$ & $\begin{array}{c}38.93 a \pm \\
0.14\end{array}$ & $\begin{array}{c}454.74 \mathrm{c} \pm \\
0.13\end{array}$ & $\begin{array}{c}16.54 \mathrm{~b} \pm \\
0.10\end{array}$ & $\begin{array}{c}29.60 \mathrm{~b} \pm \\
0.17\end{array}$ & $27.36 \mathrm{a} \pm 0.60$ & & $\begin{array}{c}1.45 b \pm \\
0.04\end{array}$ & & $0.20 c \pm 0.01$ \\
\hline 66. & $\begin{array}{l}\text { Pisum sativum L (mg/100 g) } \\
\text { [104] }\end{array}$ & 262 a & 756 & 61 & $\begin{array}{l}84.06 \\
{[105]}\end{array}$ & $3.97[105]$ & 8 & & & & \\
\hline & & 69.61 & 9038 & & & & & & 37.1 & & 41.2 \\
\hline 67. & Foeniculumvulgare $(\mu \mathrm{g} / \mathrm{g})[106]$ & \pm 0.532 & $\begin{array}{c} \pm 571.0 \\
{[59]}\end{array}$ & & & $212.56 \mathrm{~cd}$ & $451.02 d$ & $0.53 a$ & $\begin{array}{c} \pm 1.220 \\
{[17]}\end{array}$ & $9.00 \mathrm{~b}$ & \pm 1.264 \\
\hline & & [59] & & & & & & & & & \\
\hline 68. & Morus alba (ppm) [107] & $160.65 \pm 1.45$ & $0.94 \pm 0.02$ & $\begin{array}{l}0.02 \pm \\
0.001\end{array}$ & $\begin{array}{l}0.04 \pm \\
0.001\end{array}$ & $\begin{array}{c}20.08 \pm \\
0.52\end{array}$ & $47.90 \pm 2.23$ & $\begin{array}{c}<0.006 \pm \\
0.001\end{array}$ & $1.61 \pm 0.01$ & $0.34 \pm 0.01$ & $3.95 \pm 0.07$ \\
\hline 69. & $\begin{array}{l}\text { Moringa oleifera (ppm) } \\
{[108]}\end{array}$ & & $732 \pm 164$ & $602 \pm 122$ & $4 \mathrm{BDL}$ & $\mathrm{BDL}$ & BDL & $\mathrm{BDL}$ & & & \\
\hline 70. & $\begin{array}{l}\text { Ipomoea batatas (mg/100g) } \\
\text { [109] }\end{array}$ & $4.23 \pm 0.02$ & $4.50 \pm 0.01$ & $\begin{array}{c}28.44 \pm \\
0.03\end{array}$ & $\begin{array}{c}340.00 \pm \\
0, .17\end{array}$ & $\begin{array}{l}0.08 \pm \\
0.00\end{array}$ & & $\begin{array}{l}16.00 \pm \\
0.04\end{array}$ & $0.00 \pm 0.00$ & & $4.64 \pm 0.10$ \\
\hline 71. & Rumexsagittatus (mg/100g) & & & & & & & & & & \\
\hline 11. & [110] & 0.177 & 3 & 2.31 & 0.703 & 39 & 441 & & 14 & & 80 \\
\hline 72. & $\begin{array}{l}\text { Taraxacumofficinale }(\mathrm{mg} / \mathbf{1 0 0 g}) \\
\text { [111] }\end{array}$ & & & & & 88 [112] & $20.06 \pm 0.009$ & $\begin{array}{l}0.08 \pm \\
0.005\end{array}$ & $1.35 \pm 0.02$ & $\begin{array}{l}0.21 \pm \\
0.004\end{array}$ & $1.79 \pm 0.03$ \\
\hline
\end{tabular}


Citation: Hassan W, Rehman S, Noreen H, Gul S, Kazmi SNZ, et al. (2015) Metallic Content of One Hundred (100) Medicinal Plants. J Nutr Disorders Ther 5: 177. doi:10.4172/2161-0509.1000177

Page 4 of 9

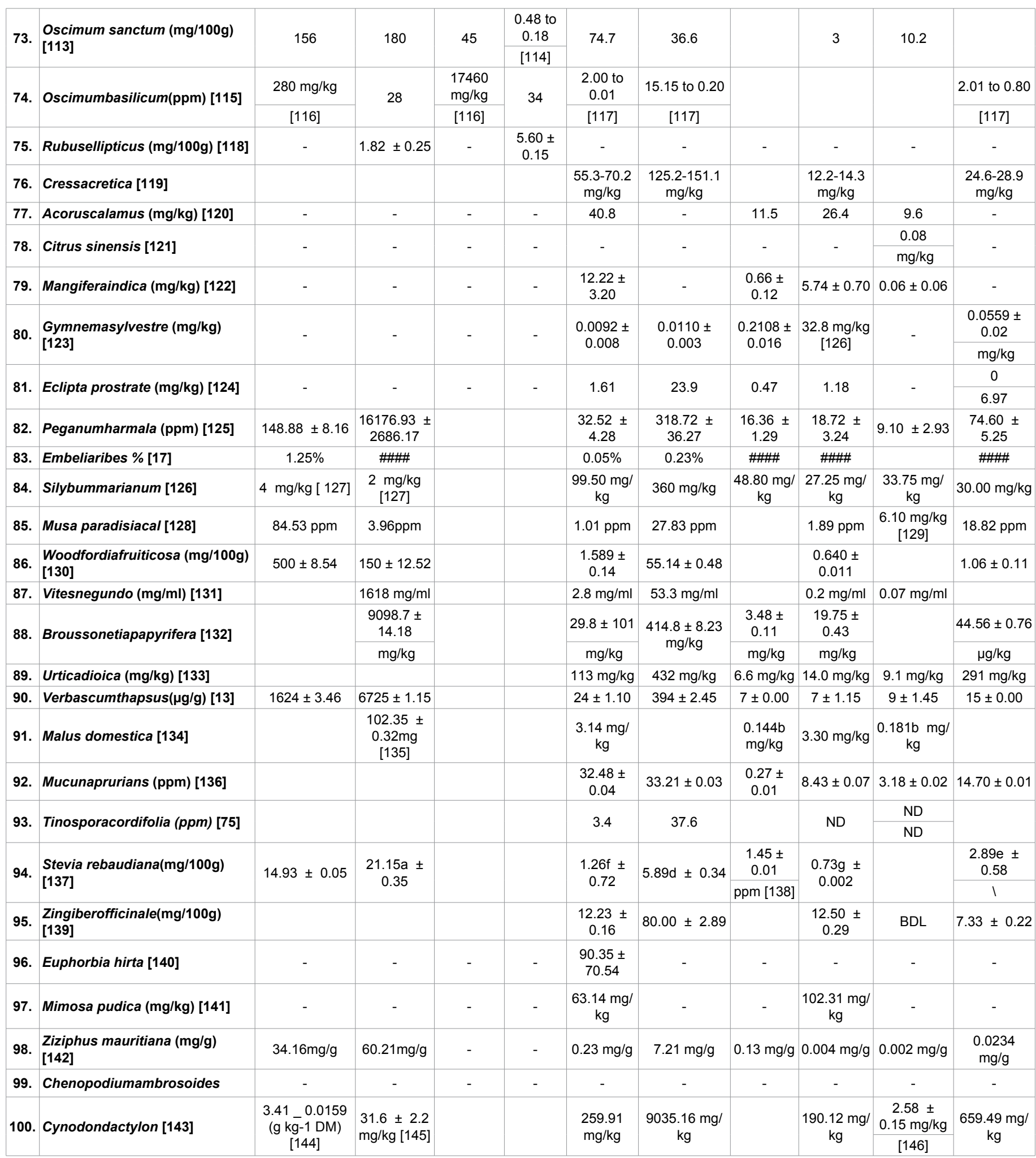

Table 1: Metallic Contents of 100 Medicinal Plants.

mean $\mathrm{Na}$ value for all the other plants is projected as $\pm 1400 \mathrm{mg} / \mathrm{kg}$. The recommended daily minimum intake of $\mathrm{Na}$ is estimated as 2400 $\mathrm{mg}$ [12]. $\mathrm{Na}$ exists as the primary cation in extracellular fluids and is known for regulation of membrane potentials, cell permeability, muscle irritability, conduction of nerve impulses and keeping a constant osmotic pressure $[8,13,14]$. Hypernatremia results due to excess serum concentration of $\mathrm{Na}$ and this has been suggested as a consequence of various factors such as, administration of several hormones, excessive release of adrenocorticotropin in Cushion's disease and diabetes insipidus whereas hypernatremia is reported in diarrhea, vomiting, 
severe burns, nephrosis, intestinal obstruction and Addison's disease [7].

The potassium $(\mathrm{K})$ content of the plants ranged from $0.0024 \mathrm{ppm}$ in D.sisso to $(1618 \mathrm{mg} / \mathrm{mL})$ in $V$. negundo, whereas the average $\mathrm{K}$ content of the other selected plants is found as $\pm 6000 \mathrm{mg} / \mathrm{kg}$. D.stromium $(295.10 \mathrm{mg} / \mathrm{g})$. E.ribes (21.5\%), S.cordifolia (10.21\%), C.limon $(8600.00$ $\pm 0.028 \mathrm{mg} / 100 \mathrm{~g})$, W.somnifera (2.2\%), and A.modesta (19000 ppm) are also considered as good sources of $\mathrm{K}$ as their $\mathrm{K}$ values are far more higher than the minimum $\mathrm{K}$ daily intake value which is $3500 \mathrm{mg}$ [12]. The importance of $\mathrm{K}$ is speculated from its participation in large number of biological processes such as acid base balance, movement of muscles, nerve impulse conduction and regulation of osmotic pressure. $\mathrm{K}$ is the major cation present in the intracellular fluid, its reduced concentration has been associated with paralysis, muscular weakness, mental confusions $[7,8,14]$, cardiac arrhythmias, defects in renal functions and carbohydrate tolerance $[15,16]$.

The data obtained from literature (Table 1) revealed the presence of calcium $(\mathrm{Ca})$ in highest concentration in plants like S.cordifolia $(13.09 \%)$ followed by C.limon $(8452.50 \pm 0.050 \mathrm{mg} / 100 \mathrm{~g})$ and A.vasica $(20900$ $\mathrm{ppm})$, while lowest Ca contents are estimated in M. alba $(0.02 \mathrm{ppm}), C$. longa $(0.12 \mathrm{ppm})$ and C.cyminum $(0.96 \mathrm{ppm})$. The recommended daily $\mathrm{Ca}$ intake required for normal biochemical activities of the body is 1500 $\mathrm{mg}$. Ca is known as an indispensible macro mineral for the composition of bones and teeth. Ca deficiency implements rickets and osteomalacia in children and adults, respectively. This may also contribute in the pathogenesis of osteoporosis resulting in weak and porous bones and considerable high risks of fracture $[8,11]$. Ca plays significant role in membrane permeability and regulates the transmission of nerve impulses, any decrease in the extracellular blood Ca may results in tetany and convulsions, due to impetuous discharges of nerve impulses $[17,7,8]$. Ca converts prothrombin to thrombin efficiently and thus helps in blood coagulation; it increases the absorption of dietary vitamin $\mathrm{D}$, clotting of milk and activation of enzymes such as lipase, ATPase succinic dehydrogenase. Ca ions normally aids in the strength of cardiac muscles, however excess absorption of $\mathrm{Ca}$ may cause $\mathrm{Ca}$ toxicity and leads to cardiac failure [18].

Medicinal plants such as D.stromium, C.album and A.vasica contain maximum magnesium $(\mathrm{Mg})$ contents of $307.49 \mathrm{mg} / \mathrm{g}, 45460$ ppm and 20900 ppm respectively. The minimum amount of $\mathrm{Mg}$ were found in D.sisso $(0.0074 \mathrm{ppm})$, C.deodra $(0.017 \mathrm{mg} / 100 \mathrm{~g})$ and $R$. communis $(0.19 \mathrm{ppm})$, while the mean $\mathrm{Mg}$ quantity present in all the plants is projected as \pm 350 , which is fairly in comparison with the predicted daily $\mathrm{Mg}$ value (400 ppm). $\mathrm{Mg}$ is required for teeth, bones, several enzyme systems [8] and for maintenance of osmotic pressure in extracellular fluids and plasma. $\mathrm{Mg}$ depletion results in chronic vomiting, diarrhea, vasodilation with erythema and hyperemia. More serious situations have been reported in long term deficiency of $\mathrm{Mg}$ such as neuromuscular hyperirritability and cardiac arrhythmia $[18,19]$.

Data obtained from literature concerning the quantity of zinc $(\mathrm{Zn})$ in medicinal plants revealed the presence of considerable higher amount of $\mathrm{Zn}$ in S.cordifolia (5.163\%), V.negundo (2.8 mg/ml), E.ribes (0.0450\%) and C.limon (13.94 $\pm 0.007 \mathrm{mg} / 100 \mathrm{~g})$, while G.sylvester, C.album, Z.armatum, C.cyminum, P.granatum, and R.communis contain lesser amount of $\mathrm{Zn}$ as $0.0092 \pm 0.008 \mathrm{ppm}, 0.2 \mathrm{ppm}, 0.032$ $\pm 0.012 \mathrm{mg} / 100 \mathrm{~g}, 0.401 \mathrm{ppm}, 0.430 \pm 0.001 \mathrm{mg} / \mathrm{L}$ and $0.49 \mathrm{ppm}$ respectively. The essential $\mathrm{Zn}$ value needed on daily basis is $11 \mathrm{mg}$ which is slightly less than the projected $\mathrm{Zn}$ content in the mentioned plants i. e. \pm 20 . The importance of $\mathrm{Zn}$ is elucidated from its role as a co-factor for majority of enzymes, performing remarkable functions in living systems such as cell replication and metabolism of nucleic acids and other macronutrients [20-22]. In addition, $\mathrm{Zn}$ is considered as an integral component of insulin, a key factor in protein synthesis, wound healing and repairment of tissues [8,23,24]. Decreased amount of $\mathrm{Zn}$ is associated with the metabolic disorders, growth retardation, skin abrasion and coronary heart pathologies $[18,25]$.

The occurrence of iron $(\mathrm{Fe})$ in medicinal plants is ranged from a lowest value in G.sylvestre $(0.0110 \pm 0.003 \mathrm{mg} / \mathrm{kg})$ to a quantity as much as high in V.negundo $(53.3 \mathrm{mg} / \mathrm{ml})$. The suggested mean value for $\mathrm{Fe}$ in all the plants is \pm 400 , while the daily dietary requirements of $\mathrm{Fe}$ are $15 \mathrm{mg}$. Fe exists primarily as hemoglobin and transferrin in the erythrocytes and plasma fractions of the blood, respectively. $\mathrm{Fe}$ is considered vital in composition of cytochromes, myoglobin, hemoglobin and succinate dehydrogenases as well as a co-factor for enzymes which participate in the synthesis of neurotransmitters [26]. The deficient concentrations of $\mathrm{Fe}$ intake have been associated with impairments in brain development and functioning, protein synthesis, restless legs syndrome and organogenesis [27]. Exceeded levels of Fe in various organs and tissues including brain can cause haemosiderosis, type-1 neurodegeneration, Alzheimer's disease and Parkinson's disease $[7,8]$. The role of $\mathrm{Fe}$ in the body is clearly allied with the transfer of oxygen from lungs to the tissue cells and hemoglobin [28] moreover; its lack is the most rampant nutritional deficit in humans and is usually caused by deficient dietary intake [29]. Furthermore, S.cordifolia having (1.309\%) of chromium ( $\mathrm{Cr}$ ) is considered to be the rich Cr containing medicinal plant, while the minimum $\mathrm{Cr}$ concentration was found in C.sativum $(<0.003 \mathrm{ppm})$ of all the selected plants for this review. The FAO/WHO estimated permissible value of $\mathrm{Cr}$ should not be more than $2 \mathrm{ppm}$ [30] which is in close proximity with the mean $\mathrm{Cr}$ content of all the plants, which is \pm 4 . Cr is an efficient mediator of carbohydrate metabolism and an imperative component of glucose tolerance factor (GTF), which enhances the action of insulin and sustains normal levels of glucose tolerance [8,31]. Cr deficiency leads to hyperglycemia, cataracts and atherosclerosis [32]. The role of $\mathrm{Cr}$ in maintenance of the configuration of RNA molecule, protein and lipid metabolism is also known from various animal and human studies $[31,33]$. Cr toxicity due to its increased concentration in body tissues results in impairment of liver, kidney, blood and nervous system functions and ultimately death [34,35].

The maximum amount of copper $(\mathrm{Cu})$ is present in plants like S.cordifolia (8.899\%), W.fruiticosa $(6400 \mathrm{mg} / 100 \mathrm{~kg})$ and D.stromium $(8.07 \mathrm{mg} / \mathrm{g})$, whilst A.sativum $(0.001 \pm 0.0 \mathrm{ppm})$, N.sativa $(0.03 \pm$ $0.00 \mathrm{mg} / \mathrm{kg})$, and C.papaya $(0.001 \mathrm{mg} / 100 \mathrm{~g})$ are considered as lowest $\mathrm{Cu}$ containing plants. The daily permissible value of $\mathrm{Cu}$ in diet is recommended as $900 \mathrm{mg}$ for children and adults. $\mathrm{Cu}$ is an important redox-active element and an indispensible component of various enzyme systems including ceruloplasmin, cytochrome oxidase, cytosolic superoxide dismutase and lactase. Cu facilitates the absorption and incorporation of $\mathrm{Fe}$ in hemoglobin, thus regulates hemoglobin synthesis and its deficiency may cause anemia [8,36,37]. $\mathrm{Cu}$ is also necessary for the smooth functioning of neurologic and hematologic systems [27]. However, excess amount of dietary $\mathrm{Cu}$ accumulates in liver resulting in a decline in blood hematologic concentration and $\mathrm{Cu}$ poisoning, which adversely affects the functioning of liver and as a consequence cause jaundice due to erythrocyte haemolysis [18].

Nickel (Ni) is quite low in all the selected medicinal plants ranged from $<0.006 \mathrm{ppm}$ in C.sativum to $0.07 \mathrm{mg} / \mathrm{mL}$ in V.negundo. The mean $\mathrm{Ni}$ content for all the plants is projected as \pm 2 which is comparable to 
the WHO recommended value of Ni (1.63ppm) in edible plants [38], also higher amount of $\mathrm{Ni}$ is noxious for health [39].

In addition, the absorbance of $\mathrm{Ni}$ by the body is very low [40], yet it has been suggested that Ni contribute in the metabolism of nucleic acids, preservation of membrane structure, control of prolactin and act as a key component of enzymes such as plant ureases and several hydrogenases. Also, experimental findings reported the malfunctioning of chicks and rats' liver when fed on $\mathrm{Ni}$ deficient diets [41]. Ni is present mostly in the pancreas and helps in regulation of insulin while its deficiency results in liver disorders [42].

Similarly, Manganese $(\mathrm{Mn})$ rich plants include S.cordifolia (1.863\%), D.stromium (8.49 mg/g) and T.ammi (771 $\pm 11 \mathrm{ppm})$, while A.sativum $(0.001 \pm 0.0 \mathrm{mg} / 100 \mathrm{~g})$, P.granatum $(0.033 \pm 0.002 \mathrm{mg} / \mathrm{L})$ and D.sisso $(0.03 \pm 0.01 \mathrm{ppm})$ contain lowest amounts of $\mathrm{Mn}$. Mn is required for several primary biochemical processes as it has been known as an active component of a number of enzymes including decarboxylases, transferases and hydrolyses $[8,43]$. Literature reported the pharmacological inference of $\mathrm{Mn}$ in anticipation and cure of diabetes mellitus [44]. Moreover, the existence of $\mathrm{Mn}$ in mitochondrial superoxide dismutase provides an evidence for the involvement of $\mathrm{Mn}$ in oxidative phosphorylation reactions. Optimum Mn levels maintain the normal bone structures and regulate functioning of central nervous system (CNS), while reduced amount lead to reproductive failure in both sexes [45], in addition Mn overexposure accounts for drastic effects on CNS and mood [27].

\section{Conclusion}

The human body requires a number of minerals in order to sustain good health [48]. Macro and microelements play a significant part in the metabolism, composition of certain proteins (hemoglobin and haemoprotein) and some mineral elements stay chelated with organic ligands and make them bioavailable to the body system [47-49]. The excessive amount of elements or specifically metals can lead to the generation of free radicals and consequently oxidative damage. The current study was aimed to review and compile ethnobotanical uses of 100 medicinal plants (which belongs to 53 families). The selected plants are utilized by the native people for cure of various diseases. The metallic contents of all the plants are presented here, shows that majority of the plants contain optimum values as compared with daily mineral intake standards. However, several factors may account for variations in mineral concentration of a particular plant, which include soil composition, different geographic areas and environmental changes.

\section{Reference}

1. Hussain K, Shahazad A, Zia-ul-Hussnain S (2008) An ethnobotanical survey of important wild medicinal plants of Hattar district Haripur, Pakistan. Ethnobotanical Leaflets 12: 29-35.

2. Abbasi AM, Khan, MA, Ahmed M, Zafar M (2010) Herbal medicines used to cure various ailments by the inhabitants of Abbottabad district, North West Frontier Province, Pakistan. Indian J Trad Know 9: 175-183.

3. Hamayun M (2005) Ethnobotanical profile of Utror and Gabral valleys, distric Swat, Pakistan. Ethnobotanical Leaflets 2005: 9.

4. Saqib Z, Sultan A (2005) Ethnobotany of Palas valley, Pakistan. Ethnobotanical Leaflets 2005: 28.

5. Trivedi PC (2002) Ethnobotany: An overview. Ethnobotany. Jaipur: Aavishkar publisher 1.

6. Eruvbetine D (2003) Canine Nutrition and Health. A paper presented at the seminar organized by Kensington Pharmaceuticals Nig. Ltd., Lagos.

7. Wadhwa N (2015) Textbook of Pediatric Gastroenterology, Hepatology and Nutrition: Anupam Sibal, Sarath Gopalan (eds), Akshay Kapoor, Vidyut Bhatia (co-eds) : Published by Jaypee Brothers Medical Publishers (P) Ltd, New Delhi, India; First Edition: 2015; ISBN: 978-93-5152-740-4. Indian J Pediatr

8. Murray RK, Granner DK, Mayes PA, Rodwell VW (2000) Harper's Biochemistry, (25th edtn), McGraw-Hill, Health Profession Division, USA.

9. Batra J, Seth PK (2002) Effect of iron deficiency on developing rat brain. Indian $\mathrm{J}$ Clin Biochem 17: 108-114.

10. Chakravarty I, Ghosh K (2000) Micronutrient malnutrition--present status and future remedies. J Indian Med Assoc 98: 539-542.

11. Saiki M, Vasconcellos MB, Sertié JA (1990) Determination of inorganic components in Brazilian medicinal plants by neutron activation analysis. Bio Trace Elem Res 26-27: 743-50.

12. Baysal A (2002) Fundamentals of Nutrition. Hatipoglu Press, Ankara (in Turkish).

13. Lokhande R, Singare P, Andhale M (2010) Study on Mineral content of Some Ayurvedic Indian Medicinal Plants by Instrumental Neutron Activation Analysis and AAS Techniques. Health Sci J 4: 157-168.

14. Hays VW, Swenson MJ (1985) Minerals and Bones. In: Dukes' Physiology of Domestic Animals. (10th edtn) 449-466.

15. Martin JDW, Mayers PA, Rodwell VW, Granner DK (1985) Harper's Review of Biochemistry. (20th edtn) Lange Medical Publications, California: 651-660.

16. Streeten Dh, Williams EMV (1952) Loss of cellular potassium as a cause of intestinal paralysis in dogs. J Physiol 118: 149-170.

17. Indrayan AK, Sharma S, Durgapal D, Kumar N, Kumar M (2005) Determination of nutritive value and analysis of mineral elements for some medicinally valued plants from Uttaranchal. Curr Sci 89: 1252-1255

18. Soetan KO, Olaiya CO, Oyewole OE (2010) The importance of mineral elements for humans, domestic animals and plants: A review. Afr J Food Sc 4: $200-222$.

19. Chatterjee MN, Shinde R (1995) Text book of medical biochemistry. (2nd edtn), Jaypee Brother Medical Pub Ltd, New Delhi, India, 811-846.

20. Hambiadge M (2000) Human Zinc deficiency. Tour of Nutrition Denver 130 1344-1349.

21. Atukorala TMS, Waidyanatha US (1987) Zinc and copper content of some common foods. J Nat Sci Coun Sri Lanka 15: 61-69.

22. Arinola OG (2008) Essential trace elements and metal binding proteins in Nigerian consumers of alcoholic beverages. Pak J Nutr 7: 763-765

23. Malhotra VK (1998) Biochemistry for Students (10th edtn) Jaypee Brothers Medical Publishers (P) Ltd, New Delhi, India.

24. Gebremedhin S, Enquselassie F, Umeta M (2011) Prevalence of prenatal zinc deficiency and its association with socio-demographic, dietary and health care related factors in rural Sidama, Southern Ethiopia: a cross-sectional study. BMC Public Health 11: 898

25. Prasad AS (1981) Symposia from the XII International Congress on Nutrition. Prog Clin Biol Res 77: 172-177.

26. Larkin EC, Rao CA (1990) Importance of fetal and neonatal iron; adequacy for normal development of central nervous system. Brain behaviour and iron in the infant diet 43-57.

27. Tan JC, Burns DL, Jones HR (2006) Severe ataxia, myelopathy, and periphera neuropathy due to acquired copper deficiency in a patient with history of gastrectomy. JPEN J Parenter Enteral Nutr 30: 446-450.

28. Sigel H (1978) Metals in Biological Systems. Marcel Dekker, New York 7: 241-275.

29. Reddy MB, Chidambaram MV, Bates GW (1987) Iron Transport in Microbes, Plants and Animals. VCH New York.

30. FAO/WHO (1984) Contaminants. In codex Alimentarius. (1st edtn) FAO/WHO codex Commissopn, Rome 17: 1-33.

31. Kaplan LA, Pesce AJ, Kazmierczak SC (2003) Clinical Chemistry, Theory, Analysis, Correlation. (4th edtn) Mosby, London 503-509.

32. Saner G, yüksel T, Gürson CT (1980) Effect of chromium on insulin secretion and glucose removal rate in the newborn. Am J Clin Nutr 33: 232-235.

33. Frieden E (1984) Biochemistry of the essential ultratrace elements. Plenum press, New York 1-15. 
34. Zayed AM, Terry N (2003) Chromium in the environment: factors affecting biological remediation. Plant Soil 249: 139-156.

35. Angard S (1980) Chromium, in Metals in the Environment. Academic Press In, London 111-132.

36. Cobanoglu U, Demir H, Sayir F, Duran M, Mergan D (2010) Some mineral, trace element and heavy metal concentrations in lung cancer. Asian Pac J Cancer Prev 11: 1383-1388.

37. Chandra RK (1990) Micronutrients and immune functions. An overview. Ann N Y Acad Sci 587: 9-16.

38. WHO (2005) Quality Control Methods for Medicinal Plant Materials. Revised Geneva Wong MK Tan P Wee.

39. McGrath SP, Smith S (1990) Chromium and Nickel in heavy metals in soils. In Alloway, B. J. Blackie, Glasgow 40-80.

40. Onianwa PC, et al. (2000) Cadmium and Nickel composition of Nigerian foods. J Food Compos Anal 13: 961-969.

41. Huheey JE, Keiter EA, Keiter RL (1993) Inorganic Chemistry: Principles of Structure and Reactivity, Harper Collins College Publishers, New York: 943949

42. Pendias AK, Pendias H (1992) Trace Elements in Soils and Plants. (2nd edn), CRC Press, Boca Raton, FL, USA 365.

43. Weber G, KonieczyÅ,ski P (2003) Speciation of Mg, Mn and $\mathrm{Zn}$ in extracts of medicinal plants. Anal Bioanal Chem 375: 1067-1073.

44. Debrah SK, Ayiyor JE, Denutsui D, Buah A, Nuviadenu C, et al. (2011) Elemental evaluation of some herbal plants used in Ghana using INAA. Der Pharma Chemica 3: 202-207.

45. Lokhande R, Singare $P$, Andhale M (2010) Study of mineral content of some Ayurvedic Indian medicinal plants by Neutron Activation Analysis and AAS techniques. Health Sci J 4: 163

46. Ajasa A, Bello MO, Ibrahim AO, Ogunwande IA, Olawore NO (2004) Heavy trace metals and macronutrients status in herbal plants of Nigeria. Food Chem 85: 67-71.

47. Kolasani A, Xu H, Millikan M (2011) Evaluation of mineral content of Chinese medicinal herbs used to improve kidney function with chemometrics. Food Chem 127: 1465-1471.

48. Choudhury RP, Garg AN (2007) Variation in essential, trace and toxic elemental contents in Murraya koenigii- A spice and medicinal herb from different Indian states. Food Chem 104: 1454-1463.

49. 49. Başgel S, Erdemoğlu SB (2006) Determination of mineral and trace elements in some medicinal herbs and their infusions consumed in Turkey. Sci Total Environ 359: 82-89.

50. Bachheti RK, Rai I, Joshi A, Pandey DP, Sharma A (2012) Physico-chemical and elemental analysis of ash of some medicinal plants from garhwal region, uttarakhand, india by atomic absorption spectrophotometer (aas). Int J Pharm Pharm Sci 4: 359-362.

51. Khosravinasab Z, Safarnejad A (2011) Comparison of Biochemical Characterization in Cuminum cyminum and Cuminum setifolium Seeds. IJSN 2: 874-877.

52. Ata S, Farooq F, Javed S (2011) Elemental profile of 24 common medicina plants of Pakistan and its direct link with traditional uses. J Med Plant Res 5 : 6164-6168.

53. Sandu DS, Gergen I, Trasca TI, Harmanescu M, Stef L, et al. (2010) Screening of 33 Medicinal Plants for the Microelements Content. Scientific Papers: Animal Science and Biotechnologies 43: 127-132.

54. Otunola GA, Oloyede OB, Oladiji AT, Afolayan AJ (2010) Comparative analysis of the chemical composition of three spices-Allium sativum L. Zingiber officinale Rosc. and Capsicum frutescens L. commonly consumed in Nigeria. Afr J Biotechnol 9: 6927-6931.

55. Padmini E, Valarmathi A, Rani MU (2010) Comparative analysis of chemical composition and antibacterial activities of and Menthaspicata Camellia sinensis Asian J Exp Biol Sci 1: 772-781.

56. Subramanian R, Gayathri S, Rathnave C, Raj V (2012) Analysis of mineral and heavy metals in some medicinal plants collected from local market. Asian Pac J Trop Biomed 2: 74-78.
57. Li JW, Fan LP, Ding SD, Ding XL (2007) Nutritional composition of five cultivars of Chinese jujube. Food chem 103: 454-460

58. Kirmani MZ (2011) Determination of some toxic and essential trace metals in some medicinal and edible plants of Karachi city. J Basic Appl Sci 7: 89-95.

59. Dayanand B, Raghavan A, Khanum K, Singh B (2010) In vitro antioxidant and free radical scavenging activity of Glycyrrhiza glabra root extracts. J herb med toxicol 4: 97-102.

60. Fahima NK, Janati SSF, Feizy J (2012) Chemical Composition of Agriproduct Saffron (Crocus sativus I.) Petals and its considerations as animal feed gida 37: 197-201.

61. Kizil S, Hasimi N, Tolan V, Kilinc E, Yuksel U (2010) Mineral content, essential oil components and biological activity of two mentha species (M. piperita L., M. spicata L.). Turk J Field Crops 15: 148-153.

62. Akhtar S (1992) Chemical and nutritional evaluation of Genus Acacia of the family Leguminosae of pakistan.

63. Iqbal MS, Ghafoor A, Abbasi FM, Qureshi AS, Ahmad H (2013) Study of nutritional characteristics, mineral nutrients and agro-biodiversity in black cumin (Nigella sativa L.) genotypes from Pakistan. Afr J Biotechnol 10: 14757-14766.

64. Bello AG, Abdu I (2011) Nutrient and mineral elements levels in four indigenous tree seeds in Sokoto State, Nigeria. J Plant Breed Crop Sci 3: 396-400.

65. El-Safy FS, Salem RH, Abd El-Ghany ME (2012) Chemical and nutritional evaluation of different seed flours as novel sources of protein. World J Dairy Food Sci 7: 59-65.

66. Akinyede Al, Amoo IA (2009) Chemical and functional properties of full fat and defatted Cassia fistula seed flours. Pak J Nutr 8: 765-769.

67. Ghani A, Saeed S, Ali Z, Ahmad I, Ishtiaq M (2012) Heavy metals and nutritiona composition of some selected herbal plants of Soon Valley, Khushab, Punjab, Pakistan. Afr J Biotechnol 11: 14064-14068.

68. Shehu K, Aliero AA (2010) Effects of Purple Blotch Infection on the Proximate and Mineral Contents of Onion Leaf. Int J Pharma Sci Res 1: 131-133.

69. Khan FA, Hussain I, Zahoor M, Rehman M (2011) Inorganic Contituent of Blue and White Flowering Silybum Marianum from Different Districts of Khyber pakhtoonkhawa, Pakistan. Middle East J Sci Res 7: 990-993

70. Ullah Z, Baloch MK, Khader JA, Baloch IB, Ullah R, et al. (2013) Proximate and nutrient analysis of selected medicinal plants of Tank and South Waziristan area of Pakistan. Afr J Pharm Pharmacol 7: 179-184

71. Kashmiri MA, Yasmin S, Ahmad M, Mohy-ud-Din A (2009) Characterization, compositional studies, antioxidant and antibacterial activities of seeds of Abutilon indicum and Abutilon muticum grown wild in Pakistan. Acta Chim Slov 56: 345-352

72. Shad AA, Shah HU, Bakht J (2013) Ethnobotanical Assessment and Nutritive Potential of Wild Food Plants. J Anim Plant Sci 23: 92-97.

73. Oseni OA, Olarinoye CO, Amoo IA (2011) Studies on chemical compositions and functional properties of thorn apple (Daturastramonium L) Solanaceae. Afr J Food Sci 5: 40-44

74. Rout OP, Acharya R, Gupta R, Mishra SK (2013) Analysis Of Some Essential Elements In Medicinal Plants Used In Ayurveda. IJABPT 4: 335-338.

75. Javid H, Khan AL, Rehman N, Khan F, Shinwari ZK, et al. (2009) Proximate and nutrient investigations of selected medicinal plants species of Pakistan Pak J Nutr 8: 620-624

76. Obumselu FO, Okerulu IO, Onwukeme VI, Onuegbu TU, Eze RC (2011) Phytochemical And Antibacterial Analysis Of The Leaf Extracts Of Ricinus Communis. J Basic Phyl Res 2: 68-72.

77. Khalil E, Esoh R, Rababah T, Almajwal AM, Alu'datt, MH (2012) Minerals, proximate composition and their correlations of medicinal plants from Jordan. $J$ Med Plants Res 6: 5757-5762.

78. Nzikou JM, Matos L, Bouanga-Kalou G, Ndangui CB, Pambou-Tobi NPG, et al. (2009) Chemical composition on the seeds and oil of sesame (Sesamumindicum L.) grown in Congo-Brazzaville. Adv J Food Sci Technol 1: 6-11.

79. Bhowmik S, Chowdhury SD, Kabir MH, Ali MA (2008) Chemical composition of some medicinal plant products of indigenous origin. Bangladesh Vet 25: 32-39.

80. Shakira G, Latif A, Mirza IH, Nadeem MA (2011) Macro-Minerals Concentrations 
of Major Fodder Tree Leaves and Shrubs of District Chakwal, Pakistan. Pak J Nut 10: 480-484

81. Khuda F, Iqbal Z, Zakiullah, Khan A, Nasir F, et al. (2012) Metal analysis, phytotoxic, insecticidal and cytotoxic activities of selected medicinal plants of Khyber Pakhtunkhwa. Pak J Pharm Sci 25: 51-58.

82. Hussain I, Khan FA, Khan N, Khan MA, Khan H (2011) Analysis of inorganic profile of Tribulus terrestris. Int J Phy Sci 6: 6147-6149.

83. Marcela F, Oana CT, Silvica A, Neculai M, loan B (2008) A new variety of origanum vulgare I.-denis, created at vrds bacau in ecologic agriculture condition, certified in 2007 year. J Plant Develop 15: 125-131.

84. Hussain J, Khan AL, Rehman N, Hamayun M, Shinwari ZK, Ullah W (2009) Assessment of herbal products and their composite medicinal plants through proximate and micronutrients analyses. J Med Plants Res 3: 1072-1077.

85. Haq F, Rehman S, Ahmad H, Iqbal Z, Ullah R (2012) Elemental analysis of Paeonia emodi and Punica granatum by atomic absorption spectroscopy. Am J Biochem 2: 47-50.

86. Tewari LM, Tewari G, Nailwal T, Pangtey YPS (2009) Bark factors affecting the distribution of epiphytic ferns communities. Nat Sci 7: 76-80.

87. Jena VK, Gupta S, Patel KS, Patel SC (2013) Evaluating heavy metals Contents in medicinal plant Menthalongifolia. J Mater Environ Sci 4: 384-389.

88. Ashrafi EN, Vahdati K, Ebrahimzadeh H, Mirmasoumi M (2010) Analysis of in-vitro explants mineral contents to modify medium mineral composition for enhancing growth of Persian walnut (JuglansregiaL.). J Food Agr Environ 8: 325-329.

89. Cosmulescu S, Botu M, Trandafir I (2010) Mineral Composition and Physical Characteristics of Walnut (Juglans regia L.) Cultivars Originating in Romania Selcuk J Agr Food Sci /Selcuk Tarim ve Gida Bilimleri Dergisi 24: 33-37.

90. Shabbir A, Shahzad M, Arfat Y, Ali L, Aziz RS, Murtaza G, Waqar SA (2012) Berberis lycium Royle: A review of its traditional uses, phytochemistry and pharmacology. Afr J Pharm Pharmacol 6: 2346-2353.

91. Rahimi-Madiseh M, Heidarian E, Rafieian-kopaei M (2014) Biochemical components of Berberis lycium fruit and its effects on lipid profile in diabetic rats. J HerbMed Pharmacol 3: 15-19.

92. Krishnamurthy SR, Sarala P (2010) Proximate Nutritive Values and Minera Components of Withania Somnifera(Linn.) Dunal. J Chem 7: 985-996.

93. Sah SP, Jha PK, Lamersdorf N (2002) Nutrient status of natural and healthy sissoo forest and declining plantation sissoo forest (Dalbergiasissoo, Roxb.) in Nepal. J For Sci 48: 459-466.

94. Atangwho J, Ebong PE, Eyong, EU Williams IO, Eteng MU, et al. (2009) Comparative chemical composition of leaves of some antidiabetic medicinal plants: Azadirachta indica, Vernonia amygdalina and Gongronemalati folium. Afr J Biotech 8: 4685-4689.

95. Xie D, Zhong HY, Mo J, Li ZH, Cui T, Yi CP (2007) Nutritional and medicinal quality of pear juice: next hotspot? Food 1: 41-48.

96. Igwenyi IO, Eze CA, Azoro BN, Offor CE, Nwuke CP (2011) Proximate, Mineral and Amino Acid Compositions of Irvigna gabonesis and Citrullus colocynthis Used as Soup Thickener in South Easter Nigeria. Int J Biotechn Biochem 7 : 493-499.

97. Oloyede OI (2005) Chemical profile of Unripe pulp of Carica papaya. Pak $J$ Nutr 4: 379-381.

98. Akpambang VOE, Amoo IA, Izuagie AA (2008) Comparative compositional analysis on two varieties of melon (ColocynthiscitrullusandCucumeropsis edulis) and a variety of almond (Prunusamygdalus). Res J Agr Biol Sci 4: 639642

99. Khattak MI, Khattak MI (2011) Study of Heavy Trace Metals In Some MedicinalHerbal Plants Of Pakistan. Pak J Bot 43: 2003-2009.

100. Kaymak HC, Guvenc I, Gurol A (2010) Elemental analysis of differen radish (Raphanus sativus $L$.) Cultivars by using wavelength-dispersivex-ray fluorescence spectrometry (WDXRF). Bulg J Agric Sci 16: 769-774.

101. Amoo IA, Atasie VN (2012) Nutritional and functional properties of Tamarindusindicapulp and Zizyphus spina-christifruit and seed. J Food Agri Environ 10: 16-19.
102. Jabeem T, Iqbal P, Khalil IA (1998) Amino Acid and Mineral Composition of Pea Cultivars Grpwn in Peshawar Pakistan. J Agri Res 9: 171-175.

103. Harmankaya M, Özcan MM, Karadas S, Ceyhan E (2010) Protein and minera contents of pea (Pisum sativum L.) Genotypes grown in central Anatolian region of Turkey. South-west J Hortic Biol Environ 1: 159-165.

104. Hina B, Rizwani GH, Naseem S (2011) Determination of toxic metals in some herbal drugs through atomic absorption spectroscopy. Pak J Pharm Sci 24 353-358.

105. Ameyaw Y, Barku VYA, Ayivor J, Forson A (2012) Phytochemical screening of some indigenous medicinal plant species used in the management of diabetes mellitus in Ghana. J Med Plants Res 6: 4573-4581.

106. Kawo AH, Abdullahi BA, Gaiya ZA, Halilu A, Dabai M, Dakare MA (2009) Preliminary Phytochemical Screening, Proximate And Elemental Composition Of Moringa Oleifera Lam Seed Powder Bajopas. Bayero J Pure appl Sci 2 : 96-100.

107. Antia BS, Akpan EJ, Umoren OPA (2006) Nutritive and Anti-Nutritive Evaluation of Sweet Potatoes (Ipomoea batatas) Leaves. Pak J Nutr 5: 166168.

108. Ghaly AE, Mahmoud N, Dave D (2012) Nutrient Composition of Dandelions and Its Potential as Human Food. Am J Biochem Biotech 8: 118-127.

109. Tiwari MR, Tamrakar NL, Shrestha HR, Shrestha BK, Jha RK (2006) Nutritive Value of Different Non-conventional Feeding Resources Found in Nepal. Green Field 4: 38-50.

110. Hussain I, Khan L (2010) Comparative Study on Heavy Metal Contents in Taraxacum Officinale. Int J Pharm Phytocheml Res 2: 15-18.

111. Czarnowska K, Milewska A (2000) The Content of Heavy Metals in an Indicator Plant (TaraxacumOfficinale) in Warsaw Polish. J Environ Stud 9: 125-128.

112. Pachkore GL, Dhale DA (2012) Phytochemicals, Vitamins and Minerals Content of Three Ocimum Species. IJSID 2: 201-207.

113. Ullah S, Khurram M, Ullah A, Rehman K, Khan FA (2013) Comparative Analyses of OcimumsantumStem and Leaves for Phytochemicals and Inorganic Constituents. Middle-East J Sci Res 13: 236-240.

114. Daniel, VN, Daniang IE, Nimyel ND (2011) Phytochemical Analysis And Mineral Elements Composition Of Ocimum Basilicum Obtained In Jos Metropolis, Plateau State, Nigeria. Int J Eng Tech 11: 161-165

115. Saklani S, Chandra S, Badoni PP, Dogra S (2012) Antimicrobial activity, nutritional profile and phytochemical screening of wild edible fruit Of Rubusellipticus. Int J Med Arom Plants 2: 269-274.

116. Pirzada AJ, Shaikh W, Ghani KU, Laghari KA (2009) Study of Anti-Fungal Activity and Some Basic Elements of Medicinal Plant Cressa Cretica Linn Against Fungi Causing Skin Diseases. Res Jour (Sci Ser) 41: 15-20.

117. Skorbilowicz E (2009) Aquatic Plants as Bioindicators of Contamination of Upper Narew River And Some of Its Tributaries With Heavy Metals. Environ Prot Eng 35: 66-77.

118. Orisakwe OE, Nduka JK, Amadi CN, Dike DO, Bede O (2012) Heavy metals health risk assessment for population via consumption of food crops and fruits in Owerri, South Eastern, Nigeria. Chem Cent J 6: 77

119. Ang LH, Ng LT (2000) Trace element concentration in mango (Mangifera indica L.), seedless guava (Psidium guajava L.) and papaya (Carica papaya L.) grown on agricultural and ex-mining lands of Bidor, Perak. Pertanika J Trop Agric Sci 23: 15-22.

120. Fatima N, Maqsood ZT, Khan B (2005) Study of some micronutrients in selected medicinal plants. Sci Iran 12: 269-273.

121. Jothivel S, Pillai SGP, Suburayan A (2011) Copper and Zinc Accumulation in few medicinal plants and Their Commercial Product in Tiruchirappalli Gandhi markwt, Tamilnadu, india. Afr J Basic Appl Sci 3: 223-227.

122. Prakash MMS, Kinthada PVS, Muralidhar NP (2011) Biologically estimation of heavy / toxic metals present in traditional medicinal plant - Eclipta alba. Int J Pharm Biomed Sci 2: 99-102.

123. Ghani A, Ali Z, Ishtiaq M, Maqboo M, Parveen S (2012) Estimation of macro and micro nutrients in some important medicinal plants of Soon Valley, District Khushab, Pakistan. Afr J Biotech 11: 14386-14391.

124. Chishti KA, Khan FA, Shah SMH (2011) Estimation Of Heavy Metals In The 
Seeds Of Blue And White Capitulum's Of Silybum Marianum Grown In Various Districts Of Pakistan. J Basic Appl Sci 7: 45-49.

125. Khan FA, Hussain I, Zahoor M, Rehman M (2011) Inorganic Contituent of Blue and White Flowering Silybum Marianum from Dfferent Distericts of Khyber pakhtoonkhawa, Pakistan. Middle-East J Sci Res 7: 990-993.

126. Ighodaro OM (2012) Evaluation study on Nigerian species of Musa paradisiaca Peels. Researcher 4: 17-20.

127. Kalita M, Devi A (2012) Uptake of Metals by Four Commonly Available Plan Species Collected From Crude Oil Contaminated Sites of Lakowa Oil Field. In J Agr Sci 2: 121-134.

128. Mahadkar S, Valvi S, Rathod V (2012) Nutritional assessment of some selected wild edible plants as a good source of mineral. Asian J Plant Sci Res 2: $468-472$.

129. Navneet S, Tiwari MM, Chauhan A (2010) Elementals Profile Of Traditional Some Important Medicinal Plants of Uttarakhand State, India. Report and Opinion 2: 34-36.

130. Sun J, Liu SF, Zhang CS, Yu LN, Bi J, et al. (2012) Chemical composition and antioxidant activities of Broussonetia papyrifera fruits. PLoS One 7: e32021.

131. Tack FM, Verloo MG (1996) Metal contents in stinging nettle (Urticadioica L.) as affected by soil characteristics. Sci Total Environ 192: 31-39.

132. Pinamonti F, Stringari G, Gasperi F, Zorzi G (1997) The use of compost: Its effect on heavy metals leaves in soil and plants. Resour Conserv Recy 21: 129-143.

133. Bamidele J, Akinyele OC, Akinkunmi KD (2012) Effect Of Electromagnetic Field On The Spoilage Fungi Of Some Selected Edible Fruits In Southwestern, Nigeria. J Microbiol Biotech Food Sci 2: 701-712.

134. Khan SA, Khan L, Hussain I (2008) Profile Of Heavy Metals In Selected Medicinal plants. Pak J Weed Sci Res 14: 101-110.
135. EsmatAbou-Arab A AzzaAbou-Arab A Abu-Salem MF (2010) Physicochemical assessment of natural sweeteners steviosides produced from Stevia rebaudiana bertoni plant. Afr J Food Sci 4: 269- 281.

136. Thakur S, Bawara B, Dubey A, Nandini D, Chauhan NS, et al (2009) Effect of Carumcarvi and Curcuma longa on hormonal and reproductive parameter of female rats. Int J Phytomed 1: 31-38

137. Shahid M, Hussain F (2012) Chemical Composition and Mineral Contents of Zingiberofficinale and Alpiniaallughas (Zingiberaceae) Rhizomes. Int J Chem Biochem Sci 2: 101-104.

138. Ray JG, George J (2010) Zn in Tolerant Roadside plants in Relation to the metal in the soil in south India. American-Eurasian J Agric Environ Sci 9: 548559.

139. Ashraf MA, Maah MJ (2011) Heavy metals accumulation in plants growing in ex tin mining, catchment. Int J Environ Sci Tech 8: 40-416.

140. Niamat R, Khan MA, Khan KY, Ahmad M, Ali B, et al, (2012) Element Content of Some Ethnomedicinal Ziziphus Linn. Species Using Atomic Absorption Spectroscop Technique. J Appl Pharm Sci 2: 96-100.

141. Sekabira K, Oryem-Origa H, Mutumba G, Kakudidi E, Basamba TA 2011) Heavy metal phytoremediation by Commelinabenghalensis $(L)$ and Cynodondactylon (L) growing in Urban stream sediments. Int J Plant Physio Biochem 3: 133-142.

142. Rathore M (2009) Nutrient content of important fruit trees from arid zone of Rajasthan. J Hortic For 1: 103-108.

143. Ameh GI, Nwammoh AO (2010) Phytochemical and Ethnobotanical Evaluation of Garlic Bulb (Allium sativum L.). Bio Res 8: 618-621.

144. Madejón P, Murillo JM, Marañón T, Cabrera F (2006) Bioaccumulation of trace elements in a wild grass three years after the Aznalcóllar mine spill (South Spain). Environ Monit Assess 114: 169-189. 